\title{
Dictynna
}

Dictynna

Revue de poétique latine

$11 \mid 2014$

Varia

\section{Empedoclean epic: how far can you go?}

\author{
D. P. Nelis
}

\section{(2) OpenEdition \\ Journals}

Electronic version

URL: http://journals.openedition.org/dictynna/1057

DOI: 10.4000/dictynna. 1057

ISSN: $1765-3142$

\section{Electronic reference}

D. P. Nelis, « Empedoclean epic: how far can you go? », Dictynna [Online], 11 | 2014, Online since 08 December 2014, connection on 11 September 2020. URL : http://journals.openedition.org/dictynna/ 1057 ; DOI : https://doi.org/10.4000/dictynna.1057

This text was automatically generated on 11 September 2020 .

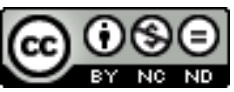

Les contenus des la revue Dictynna sont mis à disposition selon les termes de la Licence Creative Commons Attribution - Pas d'Utilisation Commerciale - Pas de Modification 4.0 International. 


\title{
Empedoclean epic: how far can you go?
}

\author{
D. P. Nelis
}

1 This paper is simply an extended footnote to P.R. Hardie's 1995 article entitled 'The Speech of Pythagoras in Ovid Metamorphoses 15: Empedoclean Epos. ${ }^{1}$ Hardie took his story of Empedoclean elements in Latin epic poetry from Ennius up to Ovid. The aim here is simply to sketch out the argument that it is relatively straightforward to extend that story one step farther and to include Lucan. ${ }^{2}$ Obviously, not every reference to cosmic matters and love and strife in Greek and Latin poetry should be traced back directly to an Empedoclean source. Equally obviously, the poetry of Empedocles was widely read and admired in antiquity, and its influence has been attracting increasing attention in recent years. This piece goes over some territory that will be familar to specialists, but if it illustrates the need for yet further work on the reception of Empedocles in Greek and Roman epic, it will have served its purpose.

2 The proem to book 3 of the Argonautica of Apollonius Rhodius, which draws on a wide range of texts dealing with erotic themes. ${ }^{3}$ Subsequently, its direct and profound influence on the prologue with which Vergil begins the second half of his epic in Aeneid 7 ensures its importance for the epic tradition. ${ }^{4}$ On the basis of the probability that in the opening lines of his third book Apollonius is alluding directly to Empedocles and making important thematic use of his poetry, it is possible to attempt to construct a literary history, in three steps. ${ }^{5}$

\section{Apollonius Rhodius and Empedocles.}

3 At the start of his third book, when invoking Erato, Apollonius Rhodius alludes to Empedocles. Compare Arg. 3. 1-5:

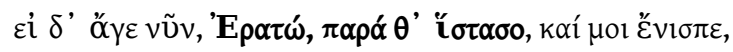

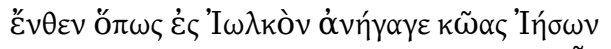

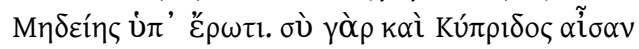




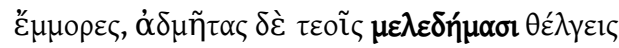

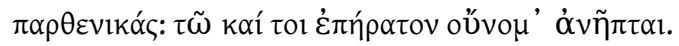
meaning 'stand beside' and in the mention of 'cares', which suggest that we are here dealing with a closer relationship, one going beyond the sharing of purely traditional elements. ${ }^{7}$ In addition, several scholars have pointed out that Apollonius draws on Empedocles at several other points in his poem, and that the Argonautica is a text in which both love and strife are important and interconnected themes. ${ }^{8}$ The song of Orpheus, which occurs early in the poem (Arg. 1.496-511) and where the ancient scholia already cite Empedocles as a model, can be seen as programmatic, as far as key aspects of the poem are concerned. By having Orpheus sing of cosmic themes Apollonius provides for the epic action of his poem, in which erotic love will play a central role, a cosmic setting marked particularly by the force of Empedoclean Strife. And from this point on, the two forces interact in complex and fascinating ways throughout the poem, particularly with regard to the erotic relationship between Jason and Medea. ${ }^{9}$

\section{Lucretius and Empedocles}

6 The fragment of Empedocles (131 DK) adapted by Apollonius in the prologue to Argonautica 3 is also relevant to the understanding of a verse of Lucretius, DRN 1.24: te sociam studeo scribendis versibus esse. Here, the request is addressed to Venus as a kind of Muse, and in asking her to act as his socia, the poet is expressing exactly the same ideas as Empedocles and Apollonius, when they request the Muse to 'stand beside' them. ${ }^{10}$ This parallel must in turn be contextualized in a broader intertextual matrix. David Sedley has argued very convincingly that the whole opening sequence of DRN 1 is thoroughly Empedoclean, with Lucretius' hymn to Venus reworking closely a hymn to Love which stood at the opening of Empedocles' On Nature. ${ }^{11}$ The precise allusion in line 24 , therefore, probably resonates in a much broader and more profound Empedoclean setting than we can imagine.

\section{Vergil and Apollonius Rhodius}

7 Aeneid 7.37 the first line of the proem to the second half of Vergil's epic, just as the proem to book 3 is the beginning of the second half of the Argonautica, is a close imitation of Argonautica 3.1, as has been long recognized. Vergil's Nunc age,..., Erato...

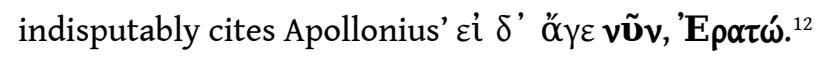

Putting together these intertextual connections, it seems that we have a sequence involving four poets: Empedocles, Apollonius Rhodius, Lucretius and Vergil. Clearly, not all of the verbal similarities between the texts are of the same precision and visibility, and some of the suggested connections convince more immediately and forcefully than others. But as always, it is necessary to contextualize detailed points of 
verbal allusion and to approach the matter from a wider perspective. One can begin to do so by formulating this question: beyond the particular detailed verbal parallels discussed thus far in this paper, what do these texts have in common? On one level, the answer to this question is that in each case the verses in question occur in a poetic prologue or invocation. And taking a step farther back, another answer is that they are all epic texts, in the sense that they are all written in hexameters. In terms of generic form, therefore, the fact that we are dealing with four epic prologues or invocations must surely be taken into consideration when weighing up the worth of any individual verbal similarity. But another question arises in response to this broadly generic approach. There is a tendency to think of the poets in question as belonging to essentially different literary traditions, by separating Apollonius and Vergil, as writers of heroic poetry, from Empedocles and Lucretius, writers of didactic/philosophical poetry. But under the influence of the work of Philip Hardie and his study of the Aeneid, Cosmos and Imperium (Oxford 1986), followed up by J. Farrell's book entitled Vergil's Georgics and the Traditions of Ancient Epic (Oxford 1991), we have come to realize that this division masks important overlapping, and that the poets play in all sorts of ways with basic generic boundaries and distinctions of the type heroic/didactic. Hence Hardie is able to link the Aeneid to poetry about the cosmos, while Farrell links the Georgics to Homeric epic by emphasizing the allegorical tradition which saw Homer as a poet of nature and science. Credit is due to both scholars for helping to bring Empedocles into perspective as a potentially important figure in the development of the classical epic tradition. ${ }^{13}$

If we are willing to accept anything like a coherent tradition in which a series of poets seems to be looking back to Empedocles as a key poetic model, obvious questions immediately come to mind. Given the fragmentary nature of the text of Empedocles and of so many other possibly relevant texts (Parmenides springs instantly to mind), how can we be sure that the intertextual connections are really 'there', as precise allusions? And even if they are 'there', how we can control their interpretation? This is not the place to get bogged down in theoretical discussion of what constitutes an allusion or in theories of intertextuality more generally. Overall, my contention is that we must be prepared to take seriously the idea that the poetry of Empedocles had a profound and lasting influence on many writers of epic in the ancient world and that he played a role in the development of the epic tradition. Even if it is not often possible to trace this literary history in any detail, it is at least important to ask the right questions and to try to come up with plausible reconstructions. Doing so will inevitably mean running the risk of going too far and attempting to build theories on fragile foundations, but this risk seems worth taking.

To begin, I would like to draw attention to two points. First, as Oliver Primavesi has reminded us by amassing the relevant evidence, Empedocles was widely read throughout antiquity. As far as we can tell, no other Presocratic author enjoyed as wide a readership..$^{14}$ Second, it is crucial to appreciate the relevance of the phenomenon variously known as 'window reference', 'looking through', 'double allusion' and 'twotier allusion', an important aspect of ancient intertextual technique which has received considerable discussion in studies of Latin poetry in recent years. ${ }^{15}$ I prefer the term 'multi-tier allusion', but whatever the terminology employed, all those who discuss this phenomenon are talking about essentially the same thing. The technique works like this, in its simplest form: when author A imitates author B, he is likely also to imitate 
the model of B, author C. So, to take one example, let Vergil = A, Apollonius Rhodius = B and Homer $=C$.

1. Vergil (A) imitates Apollonius Rhodius (B).

2. Apollonius Rhodius (B) imitates Homer (C).

3. When Vergil (A) imitates Apollonius (B) he also looks back from Apollonius to his Homeric model (C) and imitates at the same time either the Iliad or the Odyssey, or both.

There are many passages in the Aeneid in which it is possible to demonstrate that Vergil is drawing on multiple models at the same time, but doing so in a systematic way because he is fully aware of the pre-exisiting intertextual status of each of his models. For example, when Vergil compares Dido to Diana in a famous simile in book 4, he looks both to Apollonius' comparison of Medea to Artemis and to the Homeric model of that Apollonian simile, when Nausicaa is compared to Artemis. ${ }^{16}$ Once established, the tiers of allusion can become even more numerous. When Aeneas is leaving Dido in Aeneid 4, the ideal reader is able to see that Vergil is thinking (at the very least) of Homer's Odysseus and Calypso, Euripides' Jason and Medea, Apollonius' Jason and Medea and Catullus' Theseus and Ariadne, it being the case that Catullus is imitating Apollonius who is in turn imitating both Euripides and Homer. Now if we accept that this technique is a fundamental weapon in the armoury of imitative poets in antiquity, even if it is yet to be demonstrated in detail that other poets use it as systematically and pervasively as Vergil, it becomes possible to suggest that Empedocles may be present, in one way or another, in any number of intertexual patterns, in ways which we can only guess at. Let us take an obvious example first, one which has already received a considerable amount of discussion, in order to show how his approach works, before looking at a more complex case.

Vergil's account of the song of Iopas at the close of Aeneid 1 runs as follows (740-6):

$$
\text { cithara crinitus Iopas }
$$

personat aurata, docuit quem maximus Atlas.

hic canit errantem lunam solisque labores;

unde hominum genus et pecudes; unde imber et ignes;

Arcturum pluviasque Hyadas geminosque Triones;

quid tantum Oceano properent se tinguere soles

hiberni, vel quae tardis mora noctibus obstet.

The direct narrative model is Demodocus' song about Ares and Aphrodite in Odyssey 8. But this song of adultery and scandal was allegorized and read in Empedoclean terms as being about Love and Strife. Furthermore, as well as drawing on the Homeric song of Demodocus, Vergil is also using the Apollonian song of Orpheus which, as we already seen, is itself an imitation of Empedocles. So here we have an intertextual nexus involving Homer and Homer allégorisé, Empedocles, Apollonius and Vergil. ${ }^{17}$ Now of course we are not in a position to demonstrate in full detail exactly how Vergil uses Empedocles in this passage, but in recent years there has been agreement among some readers of the Aeneid that he is certainly part of the intertextual background to the epic. How big a part we will never know, but is interesting to note that Vergil's story of Dido and Aeneas is one in which love leads eventually to the strife of the Carthaginian wars. Furthermore, it is also a narrative in which the destruction of the urbs that is Troy in book 2 is presented very much in cosmic terms as the destruction of an orbis. ${ }^{18}$ And again, the narrative of the creation of the shield of Aeneas in book 8 has been read as a form of cosmogony, the round shield, created via the erotic power of Venus, displaying the history of a city destined to conquer the whole world. ${ }^{19}$ Within the 
narrative dynamic of the Aeneid, therefore, we move from love to strife against the background of a narrative involving cosmogony and cosmic dissolution. These of course may simply be the grand traditional themes of epic, and love, strife and stories of the destruction of cities and of the world all existed before Empedocles. Nevertheless, readers of Latin poetry should be encourages to search for Empedoclean epos. $^{20}$ In doing so, they do not need to worry about finding, explicating or reconstructing individual fragments. At the most general level all they need to know is whether, in front of any individual passage of Latin poetry, an educated ancient reader would have been in a position to appreciate that Empedocles represented one strand in a complex intertextual mix.

The text I would like to use to test this approach is a single sentence in Lucan, $B C$ 1.60-62, which reads as follows:

tum genus humanum positis sibi consulat armis, inque vicem gens omnis amet; pax missa per orbem

ferrea belligeri conpescat limina Iani.

These lines come from the famous passage in which Lucan praises Nero and looks forward to his apotheosis, which, the poet predicts, will coincide with the closure of the Gates of War (belligeri...limina Iani) and usher in a period of love (amet) and peace (pax). The obvious question is whether in composing this passage Lucan may have been thinking, at some level, of Empedocles. The obvious response is probably that he is not and that he is merely reworking standard epic motifs. And perhaps the matter should end there. It may, however, be worth looking at these lines a little more closely in order to get some sense of their precise meaning, the context in which they are set and their intertextual density.

What exactly does Lucan have in mind when he imagines 'peace flying over the earth', to adapt Duff's translation of the expression pax missa per orbem? Commentators tend to focus on the line which follows, referring to the closing of the Gates of War, leaving these words rather under-interpreted. But if we are setting out to look for Empedocles, two features are most immediately relevant. First, he equated the reign of Love with the absence of war and battle (fr. $128 \mathrm{DK}$ ) and therefore as an age of peace. Second, one description of the interaction between Love and Strife in the Empedoclean cycle, has been expressed in these words: 'During the time of her complete power Love is extended throughout the Sphere.... ${ }^{21}$ While we should not expect precise adherence to every single detail of the Empedoclean cycle in a poet such as Lucan, the main point to made here is that there is nothing in the image created at Bellum Civile 1.61 that is inherently contradictory in regard to one highly plausible reconstruction of Empedocles. It is noteworthy also that important aspects of Empedocles' vision of the working of his cosmic cycle have been linked to contemporary political conditions of the Greek polis, perhaps the most obvious being a comparison between Neikos and stasis. ${ }^{22}$ Lucan, of course, begins his epic by stating that his theme will be civil war, or in fact something even worse than that, Bella...plus quam civilia (1.1). Since the poem's first word bella obviously assumes a highly special thematic significance, a line referring to the closing of the gates of war, belligeri...limina Iani, is likely to merit the reader's close attention. By moving so swiftly, in the space of just 60 lines, from the opening of his poem about war to a vision of future peace, Lucan establishes right at the outset, whatever one's view of the sincerity of the praise of Nero, the possibility of a cyclic perspective on the process of Roman history ${ }^{23}$ In addition, as is well known, Lucan 
consistently presents the struggle between Caesar and Pompey and its climax at Pharsalia as a process of cosmic dissolution. ${ }^{24}$ This process too begins right at the beginning of the poem, and it concerns directly lines 60-62. The poet may look forward to the peace which he associates with Nero's apotheosis, but he immediately makes it clear that his more immediate task is to recount how peace was driven out from the earth (1.67-69):

Fert animus causas tantarum expromere rerum, inmensumque aperitur opus, quid in arma furentem inpulerit populum, quid pacem excusserit orbi.

The line-ending at 69, pacem excusserit orbi, clearly inverts the end of line 61, pax missa per orbem..${ }^{25} \mathrm{~A}$ vision of future peace is quickly replaced by an image of a world devoid of peace. In addition, the proemial gesture in the words aperitur opus, in addition to the repetition of populum, recalling its use at line 2 (populumque potentem), underscore the cyclic aspect of the narrative. ${ }^{26}$ Lucan sets up a scheme in which war and peace (which in line 61 is associated with love, amet; note also line 21 where Lucan puns both on the paradoxical love of war and indulges in the palindrome amor/Roma : amor belli...Roma) alternate in relation to the orbis, a word which appears nine times in the first hundred lines of the epic. In doing so, he looks forward to a new period of peace, but associates civil war with a return to primeval chaos and discord (1.72-80): ${ }^{27}$

$$
\begin{aligned}
& \text { sic, cum conpage soluta } \\
& \text { saecula tot mundi suprema coegerit hora } \\
& \text { antiquum repetens iterum chaos, omnia mixtis } \\
& \text { sidera sideribus concurrent, ignea pontum } \\
& \text { astra petent, tellus extendere litora nolet } \\
& \text { excutietque fretum, fratri contraria Phoebe } \\
& \text { ibit et obliquum bigas agitare per orbem } \\
& \text { indignata diem poscet sibi, totaque discors } \\
& \text { machina diuolsi turbabit foedera mundi. }
\end{aligned}
$$

Lucan's language of cosmic dissolution can be associated directly with Lucretian and Vergilian cosmic imagery. ${ }^{28}$ On one level, he has been seen as describing the destruction of the Roman world which is constructed in the Aeneid out of the atomic vision of the De Rerum Natura. But as we have already seen, for some years now Vergilian scholars have associated at least some of the cosmic imagery of the Aeneid with Empedocles, via, thanks mainly to the work of D. Sedley and M. Garani, a highly Empedoclean Lucretius. ${ }^{29}$ Is it possible to argue that Lucan could be drawing on Vergil, Lucretius and Empedocles, via the technique of window reference/double allusion/twotier allusion? If one is prepared to do so, complications immediately arise. It is obvious that in addition to these sources or models, at the opening of his epic Lucan is also drawing on (at least) Ennius, Lucretius, Vergil's Georgics and Ovid's Metamorphoses. ${ }^{30}$ Obviously, Vergil fits neatly into this intertextual nexus as an imitator in the Aeneid of Ennius, Lucretius and his own Georgics and as a central model of Ovid. But before losing sight of Lucan in so many layers of reference, let us attempt to isolate some key allusive moments, by returning once more to $\mathrm{BC} 1.62$ :

ferrea belligeri conpescat limina Iani.

This verse fits into a recurrent pattern in Latin poetry in which the gates of war are either opened or closed. This tradition begins with Ennius 225-226 (Skutsch), where the gates are opened:

postquam Discordia taetra

Belli ferratos postes portasque refregit 
Vergil reworks this description of Discordia (which is accepted as an image of Empedoclean Neikos by most scholars, taking into account also another fragment, Annales 220-221 Skutsch, corpore tartarino prognata Paluda virago/ cui par imber et ignus, spiritus et gravis terra) on two occasions, first at Aeneid 1.293-294, where they are closed:

dirae ferro et compagibus artis

claudentur Belli portae

and again Aeneid 7.607-622, where they are opened. On this occasion, Vergil's Juno and Allecto, who engineer the opening of the gates, have been seen as closely modelled on Ennius' Discordia, and therefore indirectly on Empedocles' Neikos: ${ }^{31}$

sunt geminae Belli portae (sic nomine dicunt)

religione sacrae et saeui formidine Martis;

centum aerei claudunt uectes aeternaque ferri

robora, nec custos absistit limine Ianus.

tum regina deum caelo delapsa morantis

impulit ipsa manu portas, et cardine uerso

Belli ferratos rumpit Saturnia postis.

When Lucan takes up this image, his language, as far as we can tell, draws more directly on Vergil than on Ennius, particularly in the similarity between the line-endings limina Iani (B.C. 1.62) and limine Ianus (Aen. 7.610). ${ }^{32}$ In addition to probable use of Empedocles, Ennius and Vergil, the opening of Lucan's first book is suffused with Lucretian language. ${ }^{33}$ Lucretius famously links his poem's opening to Rome's contemporary troubles, referring in lines 1.29-43 to war and the desire for peace. This contemporary reference has been used to bring down the date of the completion of the DRN to 49-48 BCE and the context of the civil war. ${ }^{34}$ Is it possible that Lucan read Lucretius' opening as a meditation on the conflict between Caesar and Pompey? Furthermore, was Lucan also in a position to appreciate Lucretius' reworking of Empedocles? In opening his poem with love, peace, war and the orbis in relation to Roman civil war, is he drawing on both models, being fully aware of the links between them? If these questions are answered positively, a further element must be considered. The opening of the first book of Lucretius is engaged in intertextual dialogue with Ennius' Annales..$^{35}$ Even if the full details of this relationship escape us, it is useful to approach the whole question of Lucretius' models in a broadly cohesive manner. The presence of both Empedoclean and Ennian sources in book 1 of the DRN can be economically explained by the fact that for Lucretius these two models were already inextricably linked in a close intertextual dialogue. It is a model based on the appreciation of multi-tier allusion which seems to offer the best way of understanding similarities between Lucretius' De Rerum Natura, Ennius' Annales (which of course opened with a section on cosmology; fr. iv. Skutsch) and Empedocles' On Nature.

One of the attractions of the approach which attempts to focus on multi-tier allusion in literary history is that once the existence of a coherent poetic tradition has been posited, it is possible to test its interpretive value by attempting to insert additional levels of allusion. Concerning the material discussed here, it is in fact possible to do precisely this, by attempting to factor in Vergil's Georgics and Ovid's Metamorphoses, poems which enjoy intertextual links with Empedocles and Lucretius, and one of which had a considerable influence on the creation of the Aeneid, while the other has been seen as the first epic rewriting of the Aeneid. 
24 At the close of book 1 of the Georgics, Vergil, in a famous passage which had very considerable influence on Lucan, as demonstrated many years ago by E. Paratore, refers to Roman civil war and seems to combine reference to both Pharsalia and Philippi, thus apparently collapsing the civil wars of the 40 s into a single event. ${ }^{36}$ I would like to suggest that given the thematic parallel between Vergil and Lucan in terms of civil war, Lucan's line-ending at 1.61, pax missa per orbem, constitutes an allusion to and pointed inversion of Georgics 1.505, tot bella per orbem and 511, saevit toto Mars impius orbe. In the Georgics, a didactic epic in which Vergil is profoundly influenced by Lucretius and famously writes about war, love (amor omnibus idem, 3.244 and of course throughout the Aristaeus-Orpheus epyllion) and the elements, Empedocles will have been an important model. ${ }^{37}$ It is perfectly natural, therefore, to interpret Lucan's prophetic picture of peace throughout the world as a direct verbal allusion to Vergil's horrific vision of the world at war, especially given that in each case it is Roman civil strife beginning from Pharsalia which is in question. When in turn it is appreciated that the closing section of Georgics 1 can be read both in Empedoclean terms as a vision of the cosmos dominated by Strife (saevit toto Mars impius orbe) and in Lucretian terms as a meditation on the possibility of restoration and salvation from chaos (Gale 32-6, 245), it seems an attractive proposition to posit the existence of a coherent intertextual nexus linking the opening of Lucan's poem to the end of Georgics 1 and also to Vergil's models there, Lucretius and Empedocles.

25 As for Ovid, we have already seen how Lucan explicitly aligns the opening of his epic with the opening of Ovid's Metamorphoses in many ways, but most obviously by means of a strikingly evident allusion to the first words of that poem. At $B C 1.67$, as he resumes his introduction to his main narrative following the laudes Neronis, we read:

Fert animus causas tantarum expromere rerum

It seems certain that many Roman readers will have picked up an echo of Metamorphoses 1.1:

In nova fert animus mutatas dicere formas

corpora

Like Lucan, Ovid refers repeatedly to the cosmic orbis and also includes precise references to the four elements, concordia and discordia $(9,60,25)$. There has of course been an enormous amount of discussion of Ovid's models in his cosmogony, and many scholars believe that it is all but impossible to isolate individual sources. ${ }^{38}$ But others have pointed out Empedoclean elements, Philip Hardie among them, and on the basis of Empedoclean allusion in both Met. 1 and 15 he has argued for an Ovidian reading of the Roman epic tradition from Ennius to Vergil as 'Empedoclean epos' ${ }^{39}$ In addition, in a recent paper I have attempted to offer an Empedoclean reading of Metamorphoses 1 as a whole, since it is a book which moves from cosmogony to cosmic dissolution, before recounting a new process of creation in a passage which seems to draw on Empedocles' zoogony..$^{40}$ There is general agreement that Ovid is also using the Apollonian song of Orpheus in Argonautica 1, the opening of Ennius' Annales and Vergil Eclogue 6, and these are all passages in which commentators suggest the presence of Empedoclean influence. So, once more, if we accept that the technique of coherent multi-tier allusion may be in operation, Empedocles may also be present as a meaningful model for readers of Lucan. In his Bellum Civile, he sets out to describe the dissolution of the Roman cosmos (always remembering that the palindromic play on Roma/amor is activated early on) in the chaos of civil strife. In so doing, he writes himself into a 
tradition of epic poetry in which he saw Empedocles as an important figure, as a brilliantly influential poet who dealt with cosmology, history, politics and all human life, and who was both an imitator of Homer, Homer allégorisé and Hesiod, and a model for Apollonius Rhodius, Ennius, Lucretius, Vergil and Ovid. It is vital, therefore, to attempt to include Empedocles in any attempt to assess the place Lucan creates for himself within a highly complex epic tradition. And having complicated matters to such an extent, I would like to finish with a question: if we are interested in exploring the reception of Empedoclean Strife and Love in Latin poetry, just how far can we go? ${ }^{41}$

\section{NOTES}

1. 'The Speech of Pythagoras in Ovid Metamorphoses 15: Empedoclean Epos', CQ 45 (1995) 204-214.

2. This paper has its origin in a talk given at a conference on the presence of the Presocratics in Latin poetry, held in Paris in on 23rd and 24th September 2010 and organised by S. Franchet d'Espèrey and Carlos Lévy. A French version will appear in due course in the proceedings of that event, to be published by the Presses de l'Université Paris-Sorbonne. I am most grateful for the permission of the editors to publish this English version here. A shorter version of some of the same material was delivered in a joint paper with Joseph Farrell, at a workshop on the poetry of Empedocles and its reception organized by Philip Hardie and myself at the Fondation Hardt, Vandoeuvres, Geneva, on 14th and 15th October, 2011. I have not gone to any great lengths to disguise the fact that the ideas presented here were first aired in the format of oral presentations. I would like to thank Valéry Berlincourt, Joseph Farrell, Lavinia Galli Milic, Alexander Hardie, and Philip Hardie for advice and encouragement of various kinds. By their generosity and learning they have helped to improve this paper in many ways, but they are in no way responsible for its remaining weaknesses.

3. See ad loc. the commentaries of R. Hunter, Apollonius of Rhodes Argonautica 3, Cambridge, Cambridge University Press, 1989 and M. Campbell, A Commentary on Apollonus Rhodius Argonautica 3.1-471, Leiden, Brill, 1994.

4. On the two passages see D. Nelis, Vergil's Aeneid and the Argonautica of Apollonius Rhodius, Leeds, Francis Cairns Publications, 2001, p. 267-75.

5. For a more detailed discussion of this material see D. Nelis, 'Apollonius Rhodius and the Traditions of Epic Poetry', in Apollonius Rhodius, Hellenistica Groningana 4, ed. M.A. Harder, R.F. Regtuit, G.C. Wakker, Leuven, Peeters 2000, p. 85-103.

6. See M.R. Wright, Empedocles: the Extant Fragments, London, Duckworth, $1995^{2}$ p. 159, S. Trépanier, Empedocles : an Interpretation, New York, Routledge, 2004, p. 57-9.

7. It is perhaps noteworthy that Hippolytus (Refutatio 7.31.3-4), who cites this fragment, makes a strong connection between the action of the Muse and Love. For discussion see S. Trépanier, op. cit. p. 59. Note also that if in line 2 we read (with, most recently, D.W. Graham, The Texts of the

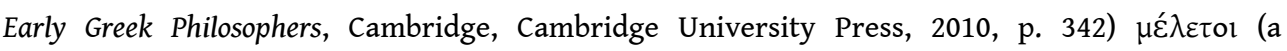
conjecture by Diels) rather than Wilamowitz's more commonly accepted ö $\delta \varepsilon \tau o$, the similarity with Apollonius is strengthened via the play on words begging with $\mu \varepsilon / \eta$ in both texts. 
8. See for example D. Nelis, 'Demodocus and the Song of Orpheus : Ap. Rhod. Arg. 1.496-511', MH 49, 1992, p. 153-70, P. Kyriakou, 'Empedoclean Echoes in Apollonius Rhodius' Argonautica', Hermes 122, 1994, p. 309-19.

9. See for example Hunter op. cit. p. 162-9.

10. See J. O'Hara, 'Venus or the Muse as 'Ally' (Lucretius, 1.24, Simonides, Frag. Eleg. 11.20-22 W)', CPh 93, 1998, p. 69-74 (1998), D. Nelis art. cit. p. 98-100.

11. See D. Sedley, Lucretius and the Transformation of Greek Wisdom, Cambridge, Cambridge University Press, (1998), chap. 1 ; for discussion of this thesis see, for example, S. Trépanier, op. cit. chap. 2. See also R. Janko 'Empedocles, On Nature I 233-364: A New Reconstruction of P. Strasb. gr. Inv. 1665-6', ZPE 150 (2004) 1-26 and O. Primavesi, Empedokles Physica I : eine Rekonstruktion des zentralen Gedankengangs, Berlin, Walter de Gruyter, 2008; a second edition of this volume is eagerly awaited.

12. For further discussion see D. Nelis, op. cit. p. 267-275.

13. For an overview see J.K. Newman, The Classical Epic Tradition, Madison, University of Wisconsin Press, 1986. For further important work which complicates and enriches our grasp of the development of the epic tradition see, for example, T. Schmit-Neuerburg, Vergils Aeneis und die antike Homerexegese, Untersuchungen zum Einfluss ethischer und kritischer Homerrezeption auf imitatio und aemulatio Vergils, Berlin, De Gruyter, 1999, M. Gale, Virgil on the Nature of Things. The Georgics, Lucretius and the Didactic Tradition, Cambridge, Cambridge University Press, 2000, P. Hardie, Lucretian Receptions, Cambridge, Cambridge University Press, 2009.

14. O. Primavesi, 'Lecteurs antiques et byzantins d'Empédocle. De Zénon à Tzétzès', in Qu'est-ce que la philosophie présocratique? ed. A. Laks, C. Louguet, Lille, Septentrion Presses Universitaires, 2000, p. 183-204.

15. See D. Nelis op. cit. 2001, p. 5 for further discussion and relevant bibliography.

16. See D. Nelis, op. cit. 2001, p. 82-86.

17. For detailed discussion see Nelis, op. cit. 96-112.

18. See Hardie, op. cit. 1986: 191-193.

19. See Hardie, op. cit. 1986: chap. 8 ; Nelis, op. cit. 345-59.

20. See Hardie, op cit. 2009 : chap. 4.

21. D. O'Brien, Empedocles' Cosmic Cycle, Cambridge, Cambridge University Press, 1969, 1. For discussion, see D. Graham, 'The Topology and Dynamics of Empedocles' Cycle', 2005 in The Empedoclean Kosmos: Structure, Process and the Question of Cyclicity, ed. A. Pierris, Patras, Institure for Pholosphical Research, 2005, p. 225-244.

22. See Graham art. cit. : 233-240. Here, and throughout this paper, I am trying to construct an argument with an Empedoclean focus. But a broader perspective is, of course, also necessary ; on Stoic ideas relating to harmony, discord and politics see for example G. Boys-Stones, 'Eros in Government : Zeno and the Virtuous City', CQ 48, 1998, p. 168-74.

23. For a related but much broader perspective on epic cyclicity see P. Hardie, The Epic Succesors of Virgil, Cambridge, Cambridge University Press, 1993, 11-14. On the importance of cyclicity, against an Empedoclean background, in the first book of Ovid's Metamorphoses, a text which was a key model for Lucan's first book, see D. Nelis, 'Ovid, Metamorphoses 1-416-51 : nova monstra and the foedera naturae', in Paradox and the Marvellous in Augustan Literature and Culture, ed. P. Hardie, Oxford, Oxford University Press, 2009, p. 248-67. More generally on Lucan and Ovid see P. Roche, Lucan De Bello Civili Book 1, Oxford, Oxford University Press, 2009, p. 25-27.

24. See M. Lapidge, 'Lucan's Imagery of Cosmic Dissolution', Hermes 107, 1979, p. 344-70, on Lucan's imagery of cosmic dissolution in purely Stoic terms; see also E. Narducci, 'Lo sfondo cosmico della Pharsalia', in Lucano e la tradizione dell'Epica latina, ed. P. Esposito, E.M. Ariemma, Università degli studi di Salerno, Quaderni del dipartimento di scienze dell' antichità, Napoli, 2004, p. 7-19.

25. See P. Roche op. cit. on 68-9. 
26. In addition, of course, the line-opening Fert animus alludes to the first line of Ovid's Metamorphoses, In nova fert animus... ; see P. Roche, op. cit. on 67, and further, below.

27. I will not discuss here the question of the sincerity of the laudes Neronis, on which see D. Nelis, 'Praising Nero (Lucan, De Bello Civili 1,33-66)', Dicere Laudes, Elogio, comunicazione, creazione del consenso, ed. G. Urso, Pisa, Edizioni ETS, 2011, p. 253-64.

28. On the pre-exisiting links between Lucretius and Vergil, i.e. links of which Lucan will have been fully aware, see Hardie, op. cit. 1986: chap. 5.

29. See Sedley, op. cit. and M. Garani, Empedocles Redivivus: Poetry and Analogy in Lucretius, New York, Routledge, 2007. Note also by the same author, 'Cosmological oaths in Empedocles and Lucretius', in Horkos. The Oath in Greek Society, ed. A. H. Sommerstein, J. Fletcher, Bristol Phoenix Press, Exeter 2007, 189-202 ; 'Revisiting Tarpeia's myth in Propertius (IV, 4)', Leeds International Classical Studies 10.3, 2011 ; 'Lucretius and Ovid on Empedoclean Cows and Sheep,' in Lucretius: Poetry, Philosophy, Science, ed. D. Lehoux, A. D. Morrison, A. Sharrock, Oxford University Press ,Oxford, New York, 2013, 233-259.

30. For recent surveys of Lucan and the Roman epic tradition see the contributions of J. Reed, S. Casali and A. Keith to Brill's Companion to Lucan, ed. P. Asso, Brill, Leiden, 2011.

31. See N. Horsfall, Virgil, Aeneid 7, Leiden, Brill, 2000, ad loc.

32. See P. Roche, op. cit. on 60-2.

33. On Lucan and Lucretius see, for example, P. Esposito, 'Lucrezio come intertesto lucaneo' BStudLat 26, 1996, p. 517-44.

34. G.O. Hutchinson, 'The Date of the De Rerum Natura', CQ 51, 2001, p. 150-162.; contra see K. Volk, 'Lucretius' Prayer for Peace and the Date of De rerum natura', CQ 60, 2010, p. 127-131. See now also C. Krebs, 'Caesar, Lucretius and the Dates of the De Rerum Natura and the Comentarii', CQ 63, 2013, 772-9.

35. See S.J. Harrison, 'Ennius and the prologue to Lucretius DRN 1 (1.1-148)', Leeds International Classical Studies 1.4 (2002) : http://lics.leeds.ac.uk/2002/200204.pdf.

36. See Nelis, art. cit. 2011, p. 259-62.

37. See D. Nelis, 'Georgics 2.458-542: Virgil, Aratus and Empedocles', Dictynna 1, 2004, http:// dictynna.revues.org/161 and A. Hardie, 'The Georgics, the Mysteries and the Muses at Rome', PCPhS 48, 2002, p. 175-208 on possible Empedoclean influence on the close of book 2 and the proem to book 3, building on the reading of P. Hardie op. cit. 1986, p. 33-51 and, more generally, on D. Ross, Virgil's Elements: Physics and Poetry in the Georgics, Princeton, Princeton University Press, 1987.

38. For detailed, insightful discussion see A. Barchiesi, Ovidio, Metamorfosi, Libri I-II, Rome, Mondadori, 2005, p. 133-58.

39. Hardie op. cit. 2009 : chap. 4.

40. See D. Nelis, 'Ovid Metamorphoses 1.416-51: nova monstra and the foedera naturae', in Paradox and the Marvellous in Augustan Literature and Culture, ed. P. Hardie, Oxford, 2009, p. 248-267.

41. New work on Empedocles and his reception can be followed on-line at: https:// sites.google.com/site/empedoclesacragas/bibliography-a-z. The research for this paper was carried out as part of a research project funded by the Swiss National Science Foundation. I would like to thank this institution for its support. 


\section{ABSTRACTS}

This paper attempts to take one step further the argument of P.R. Hardie's 1995 article in Classical Quarterly, entitled 'The Speech of Pythagoras in Ovid Metamorphoses 15: Empedoclean Epos', by showing that Lucan can be fitted easily into a version of Latin literary history that privileges the presence of recurring Empedoclean influence.

INDEX

Mots-clés: allusion, Empedocles, epic tradition, intertextuality, Lucan, reception.

\section{AUTHOR}

D. P. NELIS

University of Geneva 